\title{
The Brontë Sisters and the Christian Remembrancer: A Pilot Study in the Use of the "Burrows Method" to Identify the Authorship of Unsigned Articles in the Nineteenth-Century Periodical Press
}

\author{
ELLEN JORDAN, HUGH CRAIG, AND ALEXIS ANTONIA
}

The nineteenth-century literary scene in Britain, as readers of the Victorian Periodicals Review are well aware, was notable for the number of serious quarterly and monthly periodicals dealing with political, literary, historical, and scientific subjects of the kind that now have their own specialised academic journals. It was, however, the custom for these articles to be unsigned, and this has meant that what the editors of the Wellesley Index to Victorian Periodicals have called the "most basic questions" of the "careful scholar" - "Did So and So write on such and such a topic, and if he did, when and where was it first published?' - have often proved difficult to answer. ${ }^{\mathrm{I}}$

For more than sixty years ${ }^{2}$ both literary scholars and historians have been trying to provide answers to these questions, and a large number of indexes have been published, including the multi-volume Wellesley Index itself, where the authors of unsigned contributions to 43 nineteenth-century periodicals have been identified. ${ }^{3}$ Thus a very substantial database now exists for identifying both the literary journalism of interesting figures and commentary by the less well-remembered on major literary, social, and political issues. The task is, moreover, still ongoing, as the Curran Index and Rosemary T. VanArsdel's Victorian Periodicals: Aids to Research: A Selected Bibliography demonstrate. ${ }^{4}$ Most of this research has, however, involved the use of what Harold Love calls "external evidence': scholars have concentrated on combing surviving publisher's records, memoirs, and letters from the period for information on contrib-

Editor's Note: This experiment in using the Burrows method for tentative authorship identification of journalistic prose opens a suggestive area of research. VPR welcomes commentary on the article. 
utors to its various periodicals. 5 The more obvious literary and archival sources have, in consequence, been largely wrung dry, while the authorship of many interesting articles still remains unidentified.

The authors of this paper have begun exploring an alternative way of establishing the authorship of such articles: the method devised by Professor John Burrows of the Centre for Literary and Linguistic Computing (CLLC) at the University of Newcastle, Australia. In the early days of computer analysis of texts Professor Burrows made the discovery that the incidence of the very common words of English, the "function" words, varies significantly between texts by different authors while remaining comparatively constant within a single author's work. During the past 25 years he and his colleagues at the CLLC have been devising and refining the statistical procedures that can most effectively isolate these distinctive usages, and they now have a suite of procedures and tests that can be used to identify the authorial "signature" embedded within a text or a group of texts. ${ }^{6}$ This "Burrows method" as it is coming to be called, has to date yielded interesting results when applied to novels, poems, and plays, but, until the present authors began their investigations, it has not been used to investigate unsigned periodical literature.

We believe that our initial application of the "Burrows method" to nineteenth-century periodical literature suggests that this technique can open a new avenue within the ongoing project of attribution. Whereas most methods currently in use rely on searching for existing hard evidence of authorship, this method relies on testing hypotheses that must be devised by the scholars concerned. Most scholars using periodical literature develop hunches about who was or was not the author of particular pieces, and there are also frequent fragmentary references in letters and diaries that hint at other identifications. The "Burrows method" provides a way of testing such hypotheses, and, although unable to "prove" authorship in the way an editor's letter or a notation in a diary does, it can transform a hunch into a statistically assessable possibility.

In this article we report on the results of testing a hypothesis built on an attribution which, when the external evidence for it is examined, has proved rather shaky. Most Brontë scholars are familiar with the fact that the Christian Remembrancer carried four reviews of various publications by or concerning the three sisters. In 1975, for example, Miriam Allott printed extracts from an 1848 review of Jane Eyre, a review of Villette published in I 853, and an I 857 review of Elizabeth Gaskell's Life of Charlotte Brontë in her book The Brontës: The Critical Heritage, while in 2002 Susan Bauman reprinted a discussion of the Brontë sisters" poetry in an I 85 I article called "Minor poets."7 One of these articles, the I 853 review of Villette, is fairly generally attributed by scholars to the literary journalist Anne Mozley, while the others are accepted as unidentified. ${ }^{8}$ It seemed to 
us that the continuing significance of the Brontë sisters" work, combined with the growing academic interest in the role of female journalists, including Anne Mozley, made investigating the authorship of these articles a suitable case for testing the efficacy of the "Burrows method" in the new area of unsigned nineteenth-century periodical articles. ${ }^{9}$ We decided, therefore, to investigate not just whether the review of Villette was written by Anne Mozley, but whether she was responsible for any or all of the other three articles. We believe that our analysis has established a strong statistical likelihood that she was the author of the reviews of Villette and the Life of Charlotte Brontë and that she probably also wrote "Minor poets," but that she did not write the review of Jane Eyre.

\section{THE CHRISTIAN REMEMBRANCER}

The Christian Remembrancer is one of the journals for which no publishers" records have survived, having been issued by two minor publishing houses catering for an Anglican religious market, up to I 850 by James Burns and afterwards by J \& C Mozley. In I 843 the editorship passed to the Rev. William Scott of Hoxton and his friend the Rev. (later Dr.) J.B. Mozley, and it was transformed from a monthly into a quarterly catering for an intellectual High Church readership. ${ }^{10}$ Although most of the articles were on topics related to theology, religious history, and church politics, many issues had one article reviewing books of more general interest, with the length usually between 40 and 50 pages and including many extended quotations from the books being reviewed. In July I 847 , for example, there was a review of Tupper's Proverbial Philosophy and in August I 847 an article entitled "Children's Books.' ${ }^{\text {II }}$ This was the context in which reviews of the Brontë sisters" work appeared

The academic literature on the reception of the Brontë novels characterises the Christian Remembrancer's response as hostile, along with that

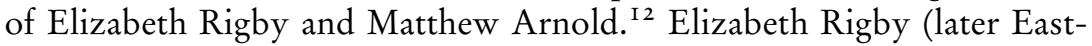
lake), writing in the Quarterly Review, described Jane Eyre as "vulgar," accused the heroine of "the worst sin of our fallen nature - the sin of pride," and argued that if the author was a woman, she must be "one who has, for some sufficient reason, long forfeited the society of her own sex," while Matthew Arnold wrote of the author that her "mind contains nothing but hunger, rebellion and rage.'I3 The Christian Remembrancer reviews acknowledged the strengths of the Brontës” work, but they, too, took issue with their morality and their subject matter. In particular, the sisters were criticised for approving rebellion against what the Church of England Catechism called "that state of life unto which it shall please God to call me" (a phrase which was interpreted to cover not only class, but health, bereavement, and social and familial obligations), and for dealing 
with coarse and ugly situations and characters, characteristics particularly to be deplored in female writers.

The I 848 review of Jane Eyre began with two accurate guesses about the author: "We for our part cannot doubt that the book is written by a female, and, as certain little provincialisms indicate, by one from the North of England ... Mr. Rochester, the hero of the story, is clearly the vision of a woman's fancy, as the heroine is the image of a woman's heart," while only a woman could have written so accurately about a girls" school. ${ }^{14}$ This reviewer also acknowledged the author's considerable talent: "She has depth and breadth of thought - she has something of that peculiar gift of genius, the faculty of discerning the wonderful in and through the commonplace - she has a painter's eye and hand - she has great satiric power, and, in spite of some exaggerated and morbid cynicism, a good fund of common sense' (408). Nevertheless, strong exception was taken to the tone and moral implications of the book:

A book more unfeminine, both in its excellences and its defects, it would be hard to find in the annals of female authorship. Throughout there is masculine power, breadth and shrewdness, combined with masculine hardness, coarseness, and freedom of expression. Slang is not rare. The humour is frequently produced by a use of Scripture, at which one is rather sorry to have smiled. The love scenes glow with a fire as fierce as that of Sappho, and somewhat more fuliginous. There is an intimate acquaintance with the worst parts of human nature, a practised sagacity in discovering the latent ulcer, and a ruthless rigour in exposing it, which must command our admiration, but are almost startling in one of the softer sex. (396)

But the reviewer went farther, and started making guesses about the character of the author:

Jane Eyre professes to be an autobiography, and we think it likely that in some essential respects it is so. If the authoress has not been, like her heroine, an oppressed orphan, a starved and bullied charity-school girl, and a despised and slighted governess (and the intensity of feeling which she shows in speaking of the wrongs of this last class seems to prove that they have been her own), at all events we fear she is one to whom the world has not been kind. And, assuredly, never was unkindness more cordially repaid. Never was a better hater. Every page burns with moral Jacobinism. "Unjust, unjust," is the burden of every reflection upon the things and powers that be. All virtue is but well masked vice, all religious profession and conduct is but the whitening of the sepulchre, all self-denial is but deeper selfishness. (397)

The second major discussion of the Brontës' work appeared in $185 \mathrm{I}$ in an article called "Minor Poets of the Day," where the book of poems the 
sisters had published in I 846 was considered alongside other more recent publications, including new works from Robert and Elizabeth Barrett Browning. IS This reviewer extended the charge of being subversive and unfeminine to all three sisters, and once again suggested that these defects must be due to their life experiences:

"Poems by Currer, Ellis, and Acton Bell" are remarkable as being the first efforts of undoubted genius to find some congenial form of expression. The sisters who have equally surprised the world, and shocked their more scrupulous readers in their debut [sic] as novelists, came before the public first in a volume of poems, which attracted very little attention at the time; nor do we know that the fame of their writings has since brought them into notice, and yet they are not common verses, but show many of the vigorous qualities which have characterized the prose works of the same writers, while they are free, though not without kindred faults, from that unscrupling, unblushing coarseness, which made it hard, in spite of so much internal evidence, to credit that "Jane Eyre" and above all "Wuthering Heights" could be from a woman's pen. It is impossible to think of the author of Jane Eyre, without perhaps unjust regrets at what must have been the faults of early training or adverse circumstances, which could have warped and obscured the whole moral views of so clear, powerful, and sympathising a mind - which could set it at permanent war with the common proprieties of life, and give her such bitter impressions of the tyranny of society over her own sex, a tyranny which she would teach them to escape from, by an abandonment of those reserves, that delicacy, which are the charm as well as the safeguard of purity of mind.

In I853, Charlotte Brontë's Villette was reviewed in the article later attributed to Anne Mozley, "New Novels by Lady G. Fullerton and Currer Bell. ${ }^{16}$ In the first part of the review the reviewer held up to ridicule the extravagances and melodrama of the novel by Georgiana Fullerton, and compared it unfavourably with Villette, where the strength of the writing and the character drawing were praised: "Currer Bell has a confined range of experience, and she, too, chooses peculiar persons, and situations on which to practise her art, but she makes them each speak and act according to their individual nature" (403). Again, however, the themes of the author's rebellion and "coarseness," and the concern with what the book revealed about her character, were reiterated:

The moral purpose of this work seems to be to demand for a certain class of minds a degree of sympathy not hitherto accorded to them; a class of which Lucy Snowe is the type, who must be supposed to embody much of the authoress's own feelings and experience, all going one way to express a character which finds itself unworthily represented by person and manner, conscious of power, equally and 
painfully conscious of certain drawbacks, which throw this superiority into shade and almost hopeless disadvantage. For such she demands room to expand, love, tenderness, and a place in happy domestic life. But in truth she draws a character unfit for this home which she yearns for. We want a woman at our hearth; and her impersonations are without the feminine element, infringers of modest restraints, despisers of bashful fears, self-reliant, contemptuous of prescriptive decorum; their own unaided reason, their individual opinion of right and wrong, discreet or imprudent, sole guides of conduct and rules of manners, - the whole hedge of immemorial scruple and habit broken down and trampled upon. (442)

Nonetheless, the success of Jane Eyre, the reviewer wrote, seemed to have "cheered her and done her good':

Perhaps, as it was argued of Gertrude [the heroine of the Fullerton novel], she has been the better for a little happiness and success, for in many important points "Villette" is an improvement on its predecessors. The author has gained both in amiability and propriety since she first presented herself to the world, - soured, coarse, and grumbling; an alien, it might seem from society, and amenable to none of its laws. (424)

This last sentence attracted the attention of other papers, and one of them, to use Charlotte Brontë's own words "culled isolated extracts from [the] review, and presented them in a concentrated form as one paragraph of unqualified condemnation." This distressed Charlotte Brontë and she wrote a dignified protest to the editor. ${ }^{\mathrm{I} 7}$

The editor responded immediately and publicly, but guilt, or at any rate remorse, lingered on, for the author of the next piece on the Brontës, a review of Elizabeth Gaskell's Life of Charlotte Brontë, actually published the letter, and apologised:

Though criticism was never more needed than in the case of Currer Bell, yet this is inevitably a sad book for critics. We do not blame ourselves for what has been said in our pages of the author of "Jane Eyre." We could not do otherwise than censure what was censurable. Where would books get their deserts, how could judgment be given, if private considerations had weight to restrain the independent public opinion? Critics would then be no better than partial friends. But such revelations as this book gives us are a lesson to weigh words. We should never forget that the unknown author has a known side; that he is not an abstraction. And here we are taught that the private side of a character may be in strong contrast to its public manifestation; that it needs a rare discernment to form a true estimate of a writer from his works; and that the boldest, most fearless style, may emanate from a nature which has its sensitive, shrinking, timid side. We believe that all the critics thought they had a tolerably tough nature to deal with, that there was no need to 
sugar the bitter draught in this instance; and when a woman assumed a masculine tone, wrote as well or better than any man amongst them, and showed herself afraid of nothing, that gallantry and patronising tenderness which is commonly bestowed upon women was changed to gall. And now the administrators of the potion have to reflect on the private most feminine sorrows of this Amazon; of a patient life of monotonous duty; of the passionate hold the purest domestic affections had on her character; and which amongst them, if he could rewrite his criticism, would not now and then erase an epithet, spare a sarcasm, modify a sweeping condemnation? We own it wounds our tenderest feelings to know her sensitiveness to such attacks; and when she sheds tears over the Times critique - of all things in the world to weep over - our heart bleeds indeed. ${ }^{\mathrm{I} 8}$

This very personal degree of contrition suggests that the author of this review may well be the same as the author of the review of Villette, which, literary tradition suggests, was written by Anne Mozley. Anne Mozley (I809-I89I), a woman intimately connected with the Christian Remembrancer, being the sister not only of J.B. Mozley, the editor, but also of the Mozley brothers whose firm published it, was one of the most determinedly anonymous of all contributors to nineteenth-century periodicals. Her name did not appear in print until she was in her eighties and edited the letters of J.H. Newman, and her position as a regular contributor to serious periodicals was scarcely known beyond her own family. ${ }^{\text {I } 9}$ A Memoir of her written by a nephew after her death revealed that she wrote serious articles on literary and social subjects not just for the Christian Remembrancer (I848-I868), but also for the Saturday Review (I86I-I877), Bentley's Quarterly Review (I859), and Blackwood's Magazine (186I-I880). ${ }^{20}$ Those written for the last two are identified in the Wellesley Index to Victorian Periodicals, while a number of those in the Saturday Review which were republished anonymously during her lifetime can, because of their mention in her nephew's Memoir, be attributed to her. ${ }^{2 \mathrm{I}}$

None of her contributions to the Christian Remembrancer have, however, been identified except for the now widely accepted attribution to her of the 1853 review of Villette. Yet the basis for this attribution is not strong, the citations going no further back than to an assertion of her authorship made by Robertson W. Nicoll in an address to the Brontë Society in 1919. ${ }^{22}$ In this address Nicoll treated it as firmly established that Anne Mozley had written this review, but gave no grounds for his belief. Yet, 20 years earlier, when he had raised the possibility in The Bookman that one of the Mozleys might have been concerned, he had stated categorically that this was pure speculation, though expressing a hope that confirmatory evidence might emerge now the question was raised. ${ }^{23}$ As far as we know, he never revealed in print why he came to 
believe that his initial guess had, by 1919, been validated, and his attribution thus seems to us a rather flimsy basis for the weight of certainty given it by present day scholars. Furthermore, we consider that if this is the only basis for believing that Mozley wrote the Villette review, surely it is just as likely, or unlikely, that she may also have written one or more of the other articles on the Brontës.

It appeared to us, therefore, that exploring the authorship of all four articles provided a useful case for a pilot study in the use of the "Burrows method" for the attribution of nineteenth-century periodical articles. On the one hand, correcting or confirming a widely accepted attribution is of importance both to Brontë scholars and to those interested more generally in the work of female journalists during this period. On the other, the respectable size of Mozley's known corpus of work and the substantial length of the Christian Remembrancer articles involved make them appropriate subjects for statistical analysis.

\section{USING THE “BURROWS METHOD”}

The first step in addressing the question of authorship using the "Burrows method" is to establish a stylistic "signature" for the putative author. This involves creating two sets of texts, a base-set known to be by the author in question, and a substantial counter-set of texts by other known writers with which the use of common words in the base-set can be compared. To avoid confusing largely generic features with authorial ones it is desirable to choose for the counter-set texts which might be expected to share these generic qualities with the base-set.

Since the Brontë articles in the Christian Remembrancer are long reviews of published books in a quarterly journal addressed to an educated audience, we decided to limit our initial choice of a counter-set to articles appearing in the more notable quarterly and monthly periodicals in the period I845-1870, and, since Anne Mozley was a woman, to select for the counter-set articles written by women whose educational background was similar to hers. For our Mozley base-set we chose six articles, five of which were published in Blackwood's Magazine and one in Bentley's Quarterly Review (Appendix A), and for the counter-set articles by six women who were publishing in the serious press during the same time period (Appendix B), selecting where possible ones (like the Rigby-Eastlake review of Jane Eyre mentioned above) that dealt with topics that featured in both the Mozley and Christian Remembrancer sets. We thus hoped to have created a closely comparable control set of texts so that Mozley's characteristic stylistic "signature" could emerge. This would, we believed, provide us with the tools for discovering whether or not it was present in any of the four Brontë articles (Appendix C). 
The 25 texts selected for the study were then transformed into e-texts by scanning, and where the photocopies available to us were unsuitable, by keyboarding. They were then proofread and prepared for analysis. We then went on to establish what we felt were the most effective methods of distinguishing Mozley's "signature" from that of the authors of the texts in the counter-set, and here a certain amount of experimentation was required. ${ }^{24} \mathrm{We}$ eventually selected two different approaches from among those that have been developed at the CLLC, believing that a triangulation of the results of two discrete tests of our hypothesis would provide a surer indication of its validity than a single method. In the first case we chose to use a cluster analysis based on the most common 250 words in the whole corpus, and in the second, frequency analysis of the texts using 50 words regularly used by Mozley and rarely used by the writers in the counter-set.

For the cluster analysis we first identified the most common 250 words appearing within the corpus of $2 \mathrm{I}$ texts by known authors (Appendix E: Table I). Then a second set of lists, showing their proportional representation in each text we were using, was prepared. Figure I shows a cluster analysis using all 250 words. Evidently there are some strong patterns which are common to the various members of the Mozley set since all of them are grouped in a single tree. On the other hand, one of the articles by Margaret Oliphant appears in the same tree, while certain articles by other authors are quite widely separated. These 250 words, we concluded, provide a rough-and-ready form of authorial discrimination and confirm the presence of authorial affinities in the data, but other factors, such as the subject matter and the genre, appeared to have intervened to cut across authorial allegiances.

Our next step, therefore, was to isolate those words out of the initial 250 that were the most significant "markers" of Mozley's style. Consequently we ran another test, the T-test, which compares the proportional usage of each of these 250 words in the Mozley set with the usage in the texts written by her contemporaries. The higher the T-value, the more systematic and marked are the differences between the two sets. We found that the T-tests incorporated into the program isolated 62 words (Appendix E: Table 2) with a T-test value of $+/-2.0$ or stronger. (For all these words the probability of the null hypothesis, that the two sets in fact belong to a single population, was .054 or less). A cluster analysis (Figure 2) using these 62 words divided the $2 \mathrm{I}$ texts into two distinct "trees," one tree containing all the Mozley texts, and the other all the texts by her contemporaries. As a confirmatory test we ran the same analysis including a group of articles taken from a rather different kind of periodical, the Saturday Review, six "middles" known to be written by Mozley, and six reviews attributed by Merle Mowbray Bevington to a Mrs. Bennett (Appendix D). ${ }^{25}$ Figure 3 shows that each of these clustered in the 


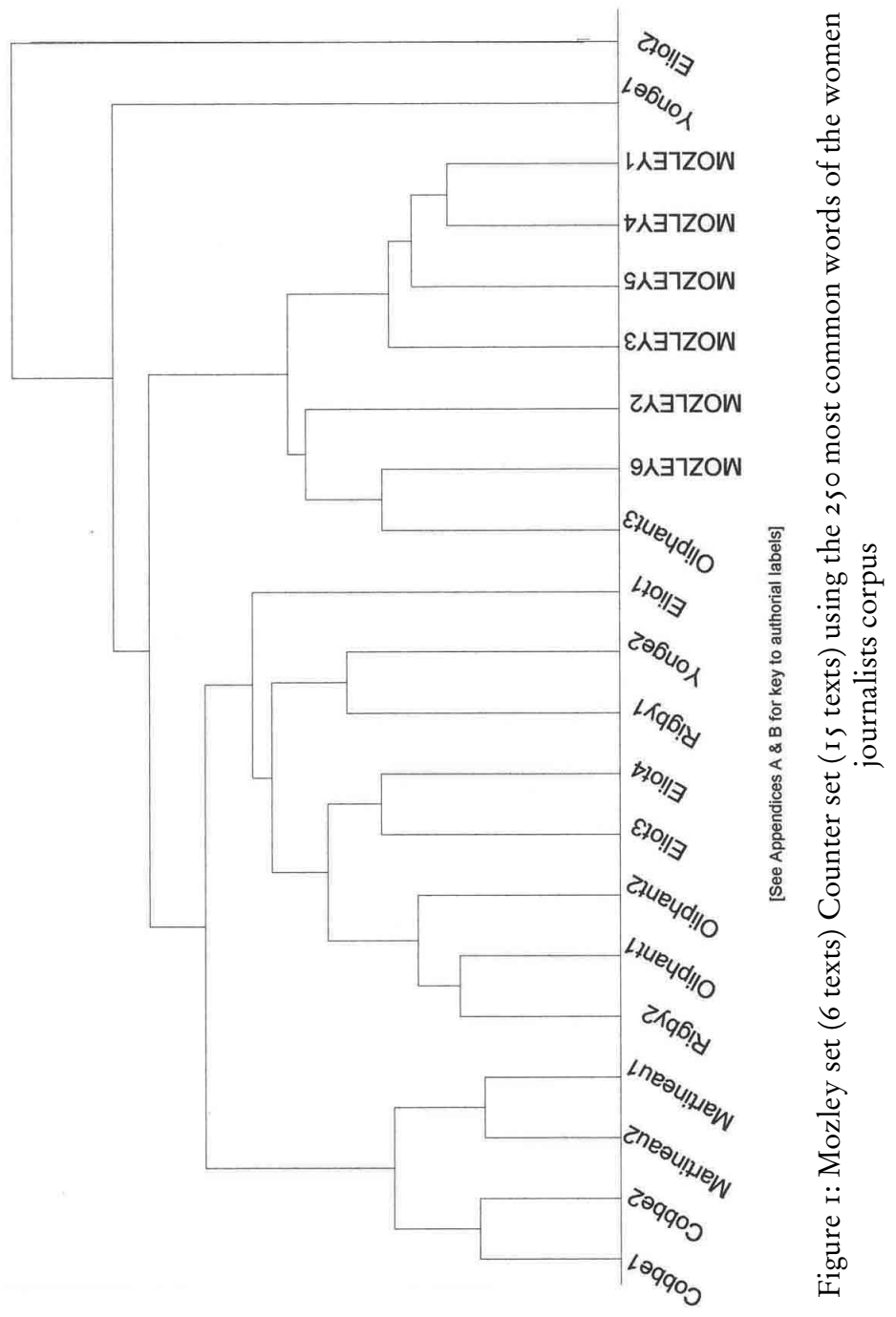




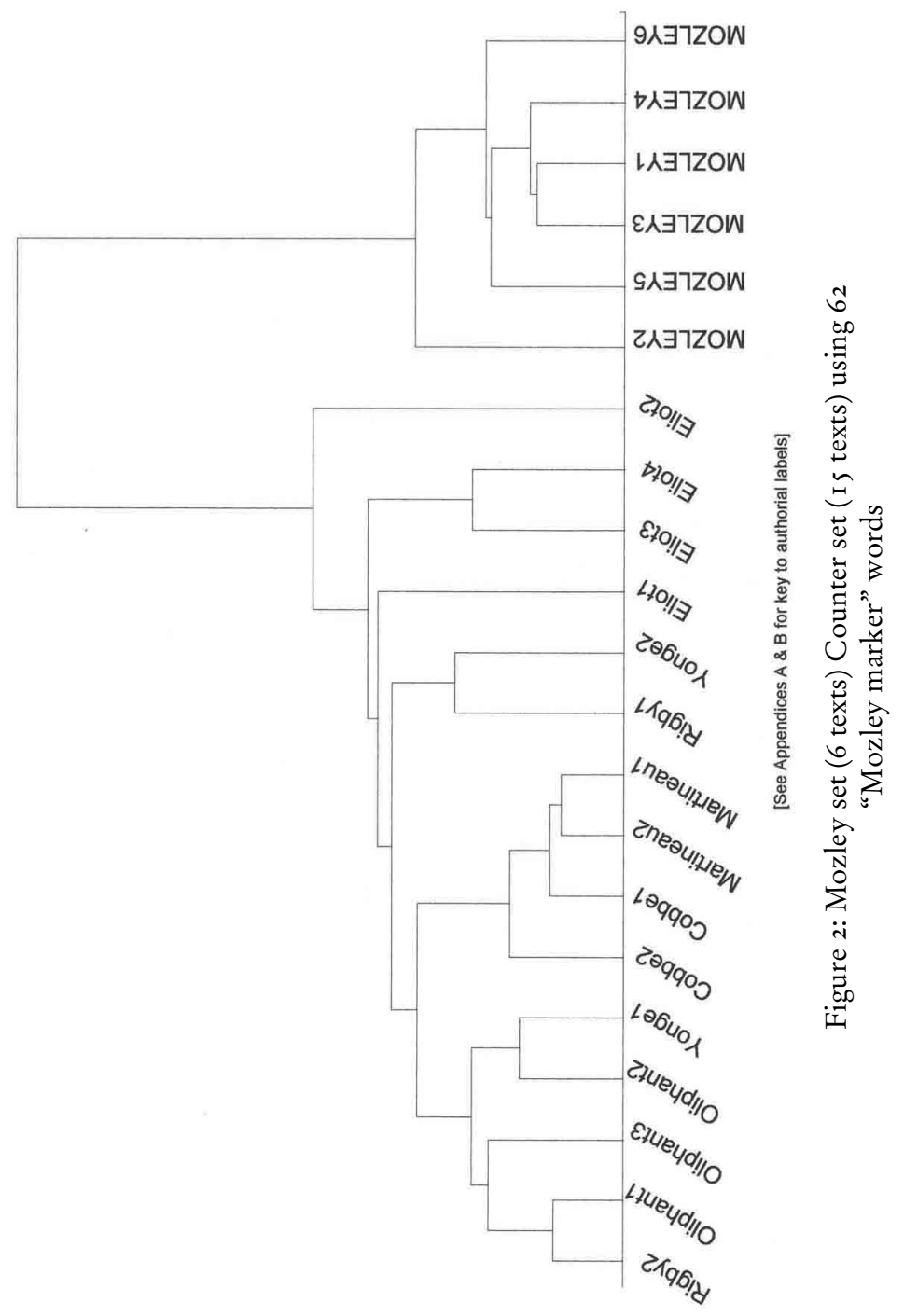


manner predicted, the Mozleys being positioned within the Mozley tree and those by Mrs. Bennett among the counter-set.

Having established that these 62 words were significant Mozley "markers," we ran a new cluster analysis on a group of texts composed of the Mozley set, the counter-set, and the set from the Christian Remembrancer. The results are shown in Figure 4. The two trees have remained as distinct as before, with the reviews of Villette, of Mrs Gaskell's Life, and of "Minor poets" clustering with the Mozley set, and the review of Jane Eyre positioned in the counter-set, suggesting that Mozley wrote three of the four articles.

Our second approach used a method still under development and tentatively called "Zeta" by its inventor, Professor Burrows. In the form of Zeta we used here the emphasis is on relatively rare words which are distinctive favourites of the base-set writer, marking him or her out from the counter-set. We selected words which occurred regularly in the Mozley articles, having at least one instance in at least four of the six articles, and rarely in the six other authors, with instances in no more than two of the authors. There were 50 that satisfied these rules. (Appendix E: Table 3)

The Zeta test and the cluster analysis used different sets of word variables and thus offer quite different selections from the word-frequency data. There are some revealing links between them, however. It turns out, for instance, that Mozley uses amongst in her essays where her fellowwriters use among. Amongst is in the list of characteristic Mozley words used for the Zeta test, and among is one of the words selected from the 250 list by the T-test, with a markedly lower mean in the Mozley texts, for use in the cluster analysis.

For tests using these 50 words we chose two measures from the various possibilities. The first was a simple measure based on instances - just adding up all the instances of the 50 words in a given text - and the second a measure based on hits, for example, how many of the chosen words appeared at all in each of the texts. Both were adjusted to take account of the length of the text used. The instances test collects all occurrences of the 50 words in a text or group of texts to calculate an overall rate of use. The hits test reports how many of the 50 words occur once or more in the same text or group of texts to give more of a sense of the spread of occurrences across the words. Once again the articles by Mozley and Bennett from the Saturday Review were used as test sets, giving an indication of how well the measures perform on texts which are of known authorship but have not been used in the base and counter sets. Scores for the Christian Remembrancer set were then calculated.

The results are shown in Figure 5. Entries are arranged by instances scores, with the highest to the left. The Mozley base set has high scores (far left) and the counter-set of articles by others (far right) has low scores. In both cases the scores are an average, for the Mozley an average 
of the six articles used, and for the others an average of the six authorial counts (for this each author's articles were combined into a composite text). The difference between the two, Mozley and non-Mozley, is no surprise, since the words were chosen with this in mind. The base-set and counter-set averages are the benchmarks for assessing the authorship of mystery pieces. The test sets (second from left, and sixth from left) fit their authorial allegiances well, the Mozley test set especially so. This latter aspect is, again, to be expected since there is likely to be greater variation from the norm among the myriad possible other authors than within the work of the single base-set author.

The instances scores (the darker-shaded columns) show a break between the Life of Charlotte Brontë essay and the "Minor Poets" one. This would indicate that the Villette review and the Life essay belong with the Mozley group, and "Jane Eyre" and "Minor Poets" belong with the non-Mozley entries. On the basis of the hits scores, however, the larger gap is between "Minor Poets" and the non-Mozley test entry, indicating that "Minor Poets" belongs with Mozley. Thus the "Zeta" test confirms the cluster analysis finding that Anne Mozley wrote the reviews of Villette and of Mrs Gaskell's Life, and that she did not write the Jane Eyre review. The status of the "Minor poets" article is more equivocal, but given its unambiguous place in the Mozley tree in the cluster analysis, it should be regarded as possible that it was written by Mozley.

In consequence, we believe that Anne Mozley's authorship of the reviews of Villette and the Gaskell Life can be placed in the highest of Harold Love's "band-categories" of attribution. Love writes: "An assured attribution or deattribution is one that is genuinely beyond reasonable doubt: a case that is supported by strong evidence of several kinds, including styolmetric, and for which there is no arguable alternative. ${ }^{26}$ In spite of the weak basis for Nicoll's attribution, Mozley's nephew's assertion that she contributed regularly to the Christian Remembrancer combines with the finding, based on two discrete statistical analyses, that they carry Mozley's distinctive authorial "signature," to place them firmly in this category. The finding that she did not write the review of Jane Eyre also seems to belong in this band. Both statistical analyses found that it did not bear Mozley's "signature," and there was no contemporary or near contemporary suggestion that she wrote it. The attribution of "Minor poets" to her is, however, not as "assured," and it would seem to belong in Love's third band of which he writes: "A tentative attribution or deattribution would characteristically be the result of a process of arbitration between one body of evidence in favour and another against, with the decision coming down on a particular side only through the balance of probabilities." Though the statistical tests produced conflicting evidence, we would argue that the fact that we can now accept that Mozley wrote two other reviews demonstrating similar atti- 


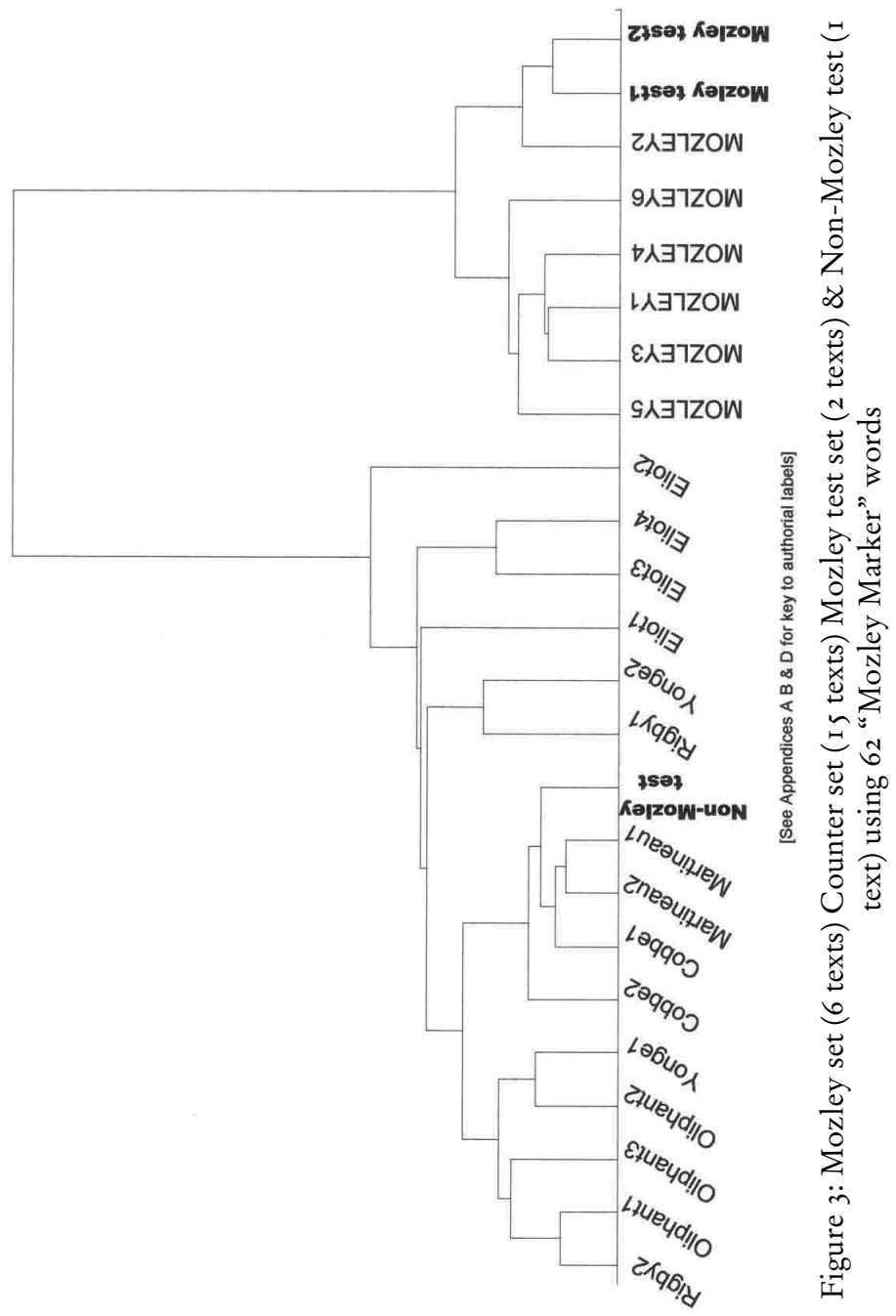




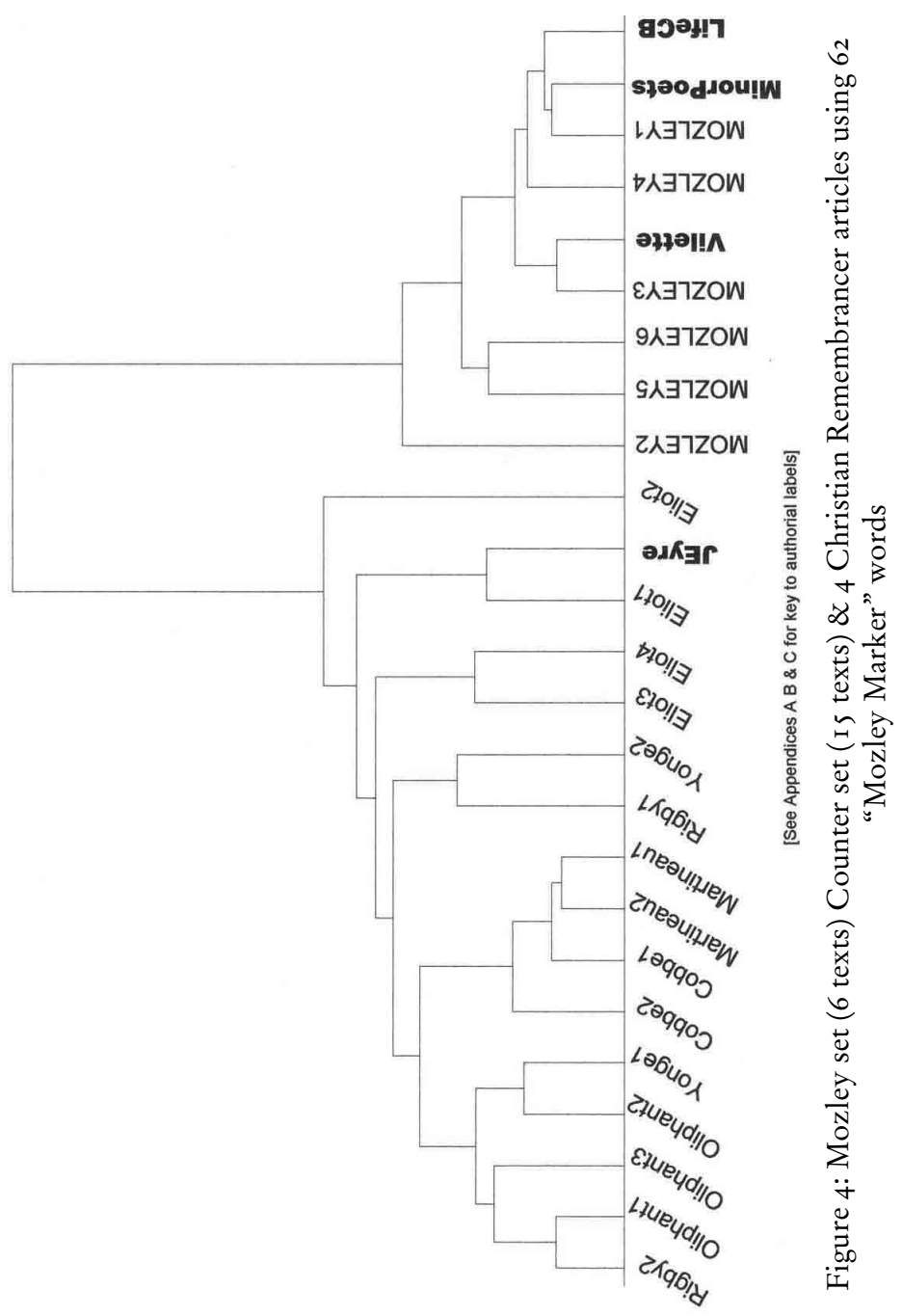



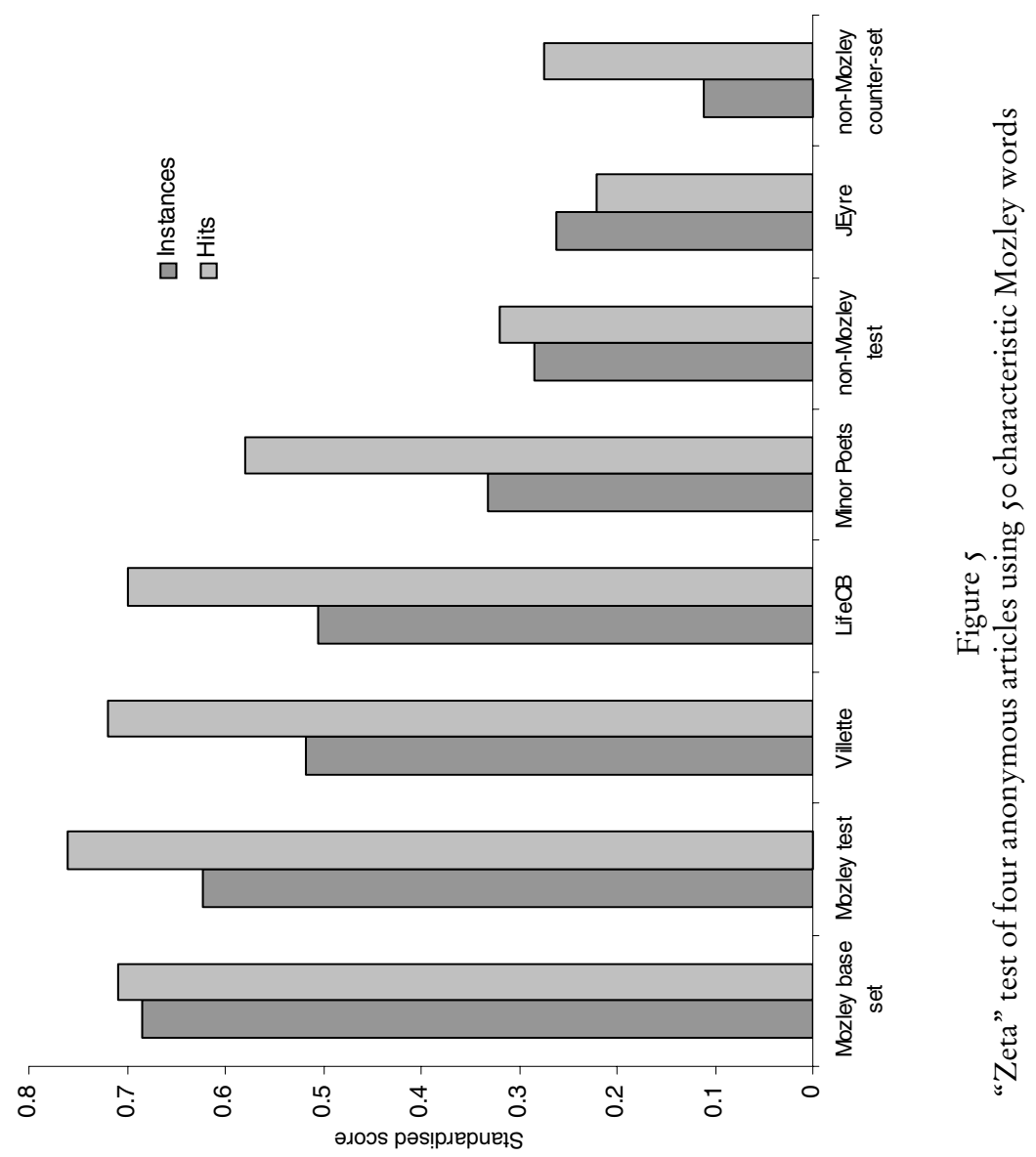
tudes to the Brontës, weights the balance of probabilities on the positive side.

\section{CONCLUSION}

In I 859 George Eliot recommended Anne Mozley's review of her novel Adam Bede to her friend and patron, Charles Bray, writing: "There is much beautiful feeling in it. The article in the Edinburgh, by Forster, though more laudatory, was less gratifying. Praise is so much less sweet than comprehension and sympathy." A few days later she reported: "Some one said the writer of the article on A.B. was a Mr Moseley a clergyman and a writer in the "Times': but these reports about authorship are as often false as true. I think it is on the whole the best review we have seen. ${ }^{27}$ She was not, however, the only leading novelist to rank a review by Anne Mozley highly. In spite of the pain the review of Villette caused her, Charlotte Brontë wrote to her publisher that it was "the cleverest of all the reviews," describing the author as a "clever, hard headed high church ecclesiastic of sinewy bigotry and genuine talent," and glorying in the fact that, even though the reviewer "would fain anathematize; excommunicate the author," her book has won "his" grudging attention and respect. ${ }^{28}$

As a result of our investigations, we believe it can now be fairly confidently stated that the two leading female novelists of the Victorian era regarded a single reviewer, Anne Mozley, as the most personally gratifying critic of their novels. Furthermore, by demonstrating that the reviewer who showed "comprehension and sympathy" for the aims and efforts of George Eliot, a rationalist in religion and a liberal in politics, reiterated in three articles her moral disapproval of the stand taken by a novelist who was, like her, an Anglican and a Tory, we may help scholars to isolate just what aspects of Charlotte Brontë's works made them appear so excitingly subversive to her contemporaries. More importantly still, however, we believe we have demonstrated that the "Burrows method" can be used to test and verify the kind of hunches scholars, and even general readers like Nicoll, can develop about the authorship of nineteenth-century periodical articles, and we hope others will consider using it for this purpose.

\section{NOTES}

I The Wellesley Index to Victorian Periodicals, I 824-I 900 (Toronto: University of Toronto Press; London: Routledge, c1966-cr1989), Vol. 5, p. vii.

2 In a private communication from Eileen Curran she has explained to us that the attribution of unsigned articles as a scholarly project began in the I930s when Ashley Thorndike and Emery Neff, professors at Columbia University, encouraged graduate students to make the intensive study of individual periodicals, even of a few years of a periodical's run, their dissertation topics. 
Many of these students then discovered that adequate understanding of a periodical must involve an attempt to identify the authorship of articles. She cites the following as examples: George Nesbitt, "Benthamite Reviewing: Twelve Years of the Westminster Review, I 824-I 836” (I934); Miriam Thrall, Rebellious Fraser's (1934); Edwin Everett, "The Party of Humanity: The Fortnightly Review and its Contributors, I 865-I 874" (1939); Leslie Marchand, The Athenaeum: A Mirror of Victorian Culture (194I); Merle Bevington The Saturday Review (I 94I); Francis Mineka, “The Dissidence of Dissent. The Montbly Repository, I 806-I838” (I944).

3 Robert A. Colby, "The Wellesley Index: Retrospect and Prospect: Introduction." Victorian Periodicals Review 27 (1994): 287-88.

4 See http://victorianresearch.org/curranindex.html and http://victorianresearch.org/ periodicals.html.

5 Harold Love, Attributing Authorship: An Introduction (Cambridge: Cambridge University Press, 200I), Chapter 4.

6 See the CLLC website at http://www.newcastle.edu.au/centre/cllc/ index.html.

7 Miriam Allott ed., The Brontës: the Critical Heritage (London: Routledge and Kegan Paul, I974), I05-I 2, 202-8, 364-370; Susan Bauman, "Minor Poets of the Day': The Christian Remembrancer Review of Poems by Currer, Ellis and Acton Bell.” Brontë Studies: The Journal of the Brontë Society 27 (2002): 219-24.

8 For example: Allott, 27-8, 202; Rebecca Fraser, Charlotte Brontë ( London: Methuen, I988), 436; Juliet Barker, The Brontës (London: Weidenfeld and Nicolson, I 994), 733-4; Margaret Smith ed., The Letters of Charlotte Brontë. Vol. 3 I 8 52-I 855 (Oxford: Clarendon Press, 2004), i 88.

9 See, for example, Valerie Sanders, Eve's Renegades: Victorian Anti-Feminist Women Novelists (London: Macmillan, I996); Nicola Diane Thompson, Reviewing Sex: Gender and the Reception of Victorian Novels (London: Macmillan, 1996); Barbara Onslow, Women of the Press in Nineteenth-Century Britain (London: Macmillan, 2000); Solveig C. Robinson, A Serious Occupation: Literary Criticism by Victorian Women Writers (Peterborough, Ont.: Broadview Press, 2003); and Joanne Wilkes, “'Clever Women’: Anne Mozley, Jane Austen and Charlotte Brontë.” (Forthcoming, 2005).

Io Letters of the Rev. J.B. Mozley, D.D. Edited by his sister (London: Rivingtons, I 885), 70-7 I, I08, I45-55; Brian Alderson, "Some Notes on James Burns As a Publisher of Children's Books." Bulletin of the John Rylands University Library of Manchester 76 (1994): 103-25.

I I The authors of these general articles seem to have had considerable latitude in the choice of subjects. James Mozley wrote to his sister Anne, May 30, i 847: “P.S. - Whoever wants the book on painting [Ruskin's] to receive due notice, must write a review of it himself. I have got the experience by my C.R. labours, that nobody will write on a subject of another person's suggestion." (A. Mozley, Letters of ... J.B. Mozley, I 82-83) 
I 2 Allott, 2 ; Sandra M. Gilbert and Susan Gubar,. The Madwoman in the Attic: The Woman Writer and the Nineteenth-Century Literary Imagination (New Haven: Yale University Press, 1979), 337; Margot Peters, Charlotte Brontë: The Style in the Novel (Wisconsin: University of Wisconsin Press, 1973), I 54 .

I 3 Elizabeth Rigby (later Eastlake), “Vanity Fair and Jane Eyre.” Quarterly Review 84 (I848): I 53-I85; M. Arnold to A.H. Clough, quoted Gilbert and Gubar, 337.

I 4 “Jane Eyre: an Autobiography. By Currer Bell." Christian Remembrancer is (I 848): 396.

Is "Minor Poets of the Day." Christian Remembrancer 2 I (I 8 5 I): 346-99.

I6 “New Novels by Lady G. Fullerton and Currer Bell." Christian Remembrancer 25 (I 853$): 40 \mathrm{I}-43$.

I7 Barker, 733-4.

I 8 “The Life of Charlotte Brontë.” Christian Remembrancer 34 (I 8 57): I35-36.

I9 Ellen Jordan, "Sister as Journalist: The Almost Anonymous Career of Anne Mozley." Victorian Periodicals Review, 37:3 (Fall 2004): 3 I 5-4I.

20 F. Mozley, "Memoir," in Anne Mozley, Essays from 'Blackwood'Brontë (Edinburgh and London: Blackwood, I892).

2 I Anne Mozley, Essays on Social Subjects: From the Saturday Review (Edinburgh and London: Blackwood, I 864); Anne Mozley, Essays on Social Subjects: From the Saturday Review: Second Series (Edinburgh and London: Blackwood, i 865).

22 W. Robertson Nicoll, "Charlotte Brontë and Anne Mozley." Transactions of the Brontë Society 29 (March I919): 255-257. We would like to thank Dr Joanne Wilkes of the University of Auckland for alerting us to the Nicoll attribution.

23 W. Robertson Nicoll, "Charlotte Brontë and One of Her Critics." The Bookman I7 (Nov. I 899): 4I-42. In spite of a fair acquaintance with the available biographical information on the Mozley family, we have come across no earlier suggestion of Mozley's authorship of the Villette review. It is possible, however, that one of her nephews, all of whom had literary and academic interests, may have told Nicoll that he was right, but, if so, no report of this has yet surfaced.

24 Although superficially, this experimentation might look as if the researchers are "fiddling the figures" to achieve a desired result, it is very different from such an exercise designed to "prove" the truth of a hypothesis. In this case "the truth" (that is, which author wrote which article) is known, and what is needed is to find the tests that separate out the texts that we know were, in this case, written by Mozley from those written by her contemporaries.

25 Mozley, Essays . From the Saturday Review; Merle Mowbray Bevington, The Saturday Review, I855-I868: Representative Educated Opinion in Victorian Britain (Columbia NY: I94I), 334. The individual texts were so short that for 
this test we combined them into longer files of roughly i०,০o० words each, which produced two files of Mozley text and one of Bennett.

26 Love, 2 I 6.

27 George Eliot, The George Eliot Letters, ed. Gordon S. Haight, 9 vols., (New Haven: Yale University Press, I954-78), Vol. III, I 48, 2 I 3-4. The "Mr Moseley" referred to was another of Anne Mozley's brothers, Thomas, a clergyman who was at this date living in Bloomsbury and writing leading articles for the Times.

28 Smith, Vol. 3, I 5 I-2. 


\section{APPENDIX A}

BASE-SET: ARTICLES WRITTEN BY ANNE MOZLEY (I809-I89I)

[Labels in bold are those used in the Figures]

MOZLEY. I859. “Adam Bede.” Bentley's Quarterly Review I. Reprinted in Mozley, Anne. I 892. Essays from Blackwood. With a Memoir by F. Mozley. Edinburgh and London: Blackwood, 304-344.

MOZLEY2. I861. “On Manners.” Blackwood's Magazine 90: I 54-165.

MOZLEY3. I866. "A Religious Novel.” Blackwood's Magazine 99: 275286.

MOZLEY4. I868. “Recit d'une Soeur.” Blackwood's Magazine 104: I65I 86.

MOZLEY5. I 869. "Convent Life.” Blackwood's Magazine 105: 607-62 I. MOZLEY6. г869. "Mr. Mill On the Subjection of Women." Blackwood's Magazine 106: 309-32 I.

\section{APPENDIX B \\ COUNTER-SET: ARTICLES KNOWN TO BE WRITTEN BY SIX OTHER FEMALE JOURNALISTS}

[Labels in bold are those used in the Figures]

FRANCES POWER COBBE (I 822-I904)

Cobber. I86r. "Social Science Congresses and Women's Part in Them." Macmillan's Magazine 5: 8I-94.

Cobbe2. I 862. "Female Charity: Lay and Monastic." Fraser's Magazine 66: $774-788$.

GEORGE ELIOT (I 8 I9-1 880)

Eliotı. I851. "The Progress of the Intellect." Westminster Review 54: 353-368

Eliot2. I 855. "Margaret Fuller and Mary Wollstonecraft." Leader 6: 988 989.

Eliot3. I 856. "Silly Novels by Lady Novelists." Westminster Review 66: 442-46I.

Eliot4. I 8 56. “Three Novels.” Westminster Review 66: 57 I-578

HARRIET MARTINEAU (I $802-1876$ )

Martineau I. 18 59. “Female Industry.” Edinburgh Review I09: 293-336.

Martineau2. I 865. "Nurses Wanted." Cornhill Magazine I I: 409-425. 
MARGARET OLIPHANT (I 828-I897)

Oliphanti. I855. "Modern Novelists - Great and Small." Blackwood's Magazine 77: 554-568.

Oliphant2. I 862. "Sensation Novels." Blackwood's Magazine 91: 564-584. Oliphant3.r869. "Mill's The Subjection of Women." Edinburgh Review I30: $572-602$.

ELIZABETH RIGBY (EASTLAKE) (I 809-I 893)

Rigbyı. I 844. "Children's Books." Quarterly Review 74: I-26.

Rigby2. I848. "Vanity Fair and Jane Eyre." Quarterly Review 84: I53I 85 .

CHARLOTTE YONGE (I823-190I)

Yonger. I867. "The La Ferronnays Family." Christian Remembrancer 53:353-388.

Yonge2. I 869. "Children's Literature of the Last Century: Part III Class Literature of the Last Thirty Years." Macmillan's Magazine 20: 448-456.

\title{
APPENDIX C
}

\author{
MYSTERY TEXTS: UNSIGNED ARTICLES \\ FROM THE CHRISTIAN REMEMBRANCER
}

I 848. "Jane Eyre: an Autobiography. By Currer Bell." i 5: 396-409. I 85 I. "Minor Poems." 21: 346-99.

I 853 . "New Novels by Lady G. Fullerton and Currer Bell." 25: 40I-43. I857. "The Life of Charlotte Brontë." 34: 87-I45.

\section{APPENDIX D}

\section{TEST SET: ARTICLES FROM THE SATURDAY REVIEW}

ANNE MOZLEY. [Essays reprinted in Essays on Social Subjects: From the Saturday Review. Edinburgh and London: Blackwood, I 865.]

"Busy people." I-IO.

"Snubbing." I I-I 9.

"Ignorance."20-29.

"Foolish Things." $30-38$.

"False Shame." 39-47.

"Fluency." 48-57.

“Contempt."58-68. 
"Dullness as a Sensation." $69-78$.

MRS. BENNETT.

"Lilliesleaf.” I:83 (i Dec. I855).

"The Lances of Lynwood." I:I02 (8 Dec. I 855 ).

"Lectures to Ladies on Practical Subjects." I:I i6 (Is Dec. i 855 ).

"The House of Elmore." I: i ig (is Dec. I855).

"Manuel de l'homme et de la femme comme il faut." I:I 40 (22 Dec. I855).

“Rachel Gray.” I:I 42 (22 Dec. I 855 ).

“Humboldt's Kleine Schriften.” I:2 I6 (I9 Jan. I 856).

"The Englishwoman in America." I:282 (9 Feb. 1856).

“Mes Souvenirs.” I:395 (5 Mar. I 856).

\section{APPENDIX E: WORD LISTS}

\section{TABLE I: WORD-VARIABLES USED IN CLUSTER ANALYSIS}

(250 most common words of women journalists' corpus in rank order) the of and to $a$ in is that it as her we which for be with are not but by she this or have all his on their at they has from no one who he an was there so more our women them than can will such would if us when its life been had what any may do some into must other were only very own mr most these him upon good woman much out little every great those many work up time men world being man even where should now too first same how way without like nature while after old young yet before under well never made less new though two could see does people mind far cannot then themselves make because whole about another herself mrs nothing through ever natural always children few class fact say society still find true nor between thought among perhaps book power question years whose character love here home last story know religious family give day you might certain real sense seems poor ever things take long course think subject rather himself whom place part moral books heart itself however against better human de present something means best both case right thus done manner said again whether ladies others miss believe once mother interest come author female lady hand almost general art thing doubt each go let English point down really common mere often put days kind need matter also hands just set god church education law wife quite readers 
TABLE 2: WORD-VARIABLES USED IN CLUSTER ANALYSIS (62 "Mozley Markers")

\begin{tabular}{|c|c|c|c|c|c|c|c|}
\hline $\begin{array}{l}\text { rank } \\
\text { order }\end{array}$ & word & $\begin{array}{l}\text { T-test } \\
\text { score }\end{array}$ & P score & $\begin{array}{l}\text { rank } \\
\text { order }\end{array}$ & word & $\begin{array}{l}\text { T-test } \\
\text { score }\end{array}$ & P score \\
\hline 1 & the & -5.16 & 0 & 126 & $\begin{array}{l}\text { becaus } \\
\mathrm{e}\end{array}$ & 3.42 & 0.0013 \\
\hline 2 & of & -4.49 & 0 & 134 & over & 2.42 & 0.019 \\
\hline 3 & and & -2.07 & 0.043 & 135 & natural & 3.68 & 0.0006 \\
\hline 5 & a & 2.1 & 0.04 & 136 & always & 3.39 & 0.0014 \\
\hline 9 & it & 2.96 & 0.0045 & 137 & children & -2.9 & 0.0069 \\
\hline 16 & with & 2.2 & 0.032 & 140 & fact & 3.48 & 0.0013 \\
\hline 18 & not & 3.52 & 0.0009 & 141 & say & 2.65 & 0.012 \\
\hline 22 & this & 2.91 & 0.0062 & 145 & tru e & -3.03 & 0.004 \\
\hline 26 & his & 4.85 & 0 & 148 & thought & 3.54 & 0.0009 \\
\hline 33 & no & -2.57 & 0.013 & 149 & among & -2.93 & 0.0051 \\
\hline 36 & he & 4.86 & 0 & 154 & years & -2.51 & 0.015 \\
\hline 37 & an & 3.31 & 0.0016 & 167 & you & -2.81 & 0.0084 \\
\hline 41 & more & -2.19 & 0.006 & 169 & certain & 4.22 & 0.0001 \\
\hline 45 & than & -2.06 & 0.0045 & 170 & real & 2.04 & 0.047 \\
\hline 57 & what & 2.45 & 0.018 & 173 & poor & -2.15 & 0.037 \\
\hline 60 & do & 2.48 & 0.016 & 179 & think & 2.88 & 0.0058 \\
\hline 64 & other & -2 & 0.051 & 181 & rather & -3.14 & 0.0029 \\
\hline 68 & own & 4.56 & 0 & 182 & himself & 4.74 & 0 \\
\hline 72 & him & 3.54 & 0.0009 & 184 & place & 2.07 & 0.044 \\
\hline 73 & upon & 2.13 & 0.0037 & 196 & somethi & 3.83 & 0.0004 \\
\hline 78 & little & -2.3 & 0.027 & 198 & best & -3.01 & 0.0042 \\
\hline 81 & those & -3.34 & 0.0016 & 202 & thus & 2.67 & 0.01 \\
\hline 100 & like & -2.74 & 0.0083 & 208 & ladies & -3.03 & 0.0048 \\
\hline 101 & $\begin{array}{l}\text { natur } \\
\mathrm{e}\end{array}$ & 2.23 & 0.03 & 209 & others & 2.5 & 0.017 \\
\hline 108 & under & 3.31 & 0.0017 & 210 & miss & -2.23 & 0.031 \\
\hline 110 & never & 3.29 & 0.0017 & 218 & lady & -2 & 0.054 \\
\hline 112 & less & -2.29 & 0.026 & 224 & doubt & 4.14 & 0.0002 \\
\hline
\end{tabular}




\begin{tabular}{|l|l|l|l|l|l|l|l|l|}
\hline 118 & does & 3.3 & 0.0019 & & 227 & let & -2.34 & 0.023 \\
\hline 119 & $\begin{array}{l}\text { peo- } \\
\text { ple }\end{array}$ & 5.8 & 0 & & 228 & english & -2.4 & 0.02 \\
\hline 121 & far & -2.71 & 0.0094 & & 237 & kind & -4.41 & 0.0001 \\
\hline 124 & $\begin{array}{l}\text { them- } \\
\text { selv }\end{array}$ & 2.98 & 0.0048 & & 244 & god & -2.2 & 0.034 \\
\hline
\end{tabular}

TABLE 3: WORD-VARIABLES USED IN “ZETA” ANALYSIS ( $5 \circ$ words regularly used by Mozley and rarely used by writers in the counter-set)

amongst acceptance allowing ashamed assumed attract belongs betray commonly conscientious consent constitutes contempt create deeper deliberate designed disposed fate fears finer gift granted induce inevitable insight issue mankind mistress motive mould perception permanently praise previous rate response rude self sign spoke strict telling temptations term uses victim vigorous virtues wanting 